\title{
PENGARUH PELATIHAN DAN PENERAPAN PENILAIAN KINERJA PERAWAT PELAKSANA TERHADAP LAYANAN ASUHAN KEPERAWATAN DI RUMAH SAKIT SWASTA KOTA MEDAN
}

\author{
1. Edisyah Putra Ritonga; ${ }^{2}$ Hamonangan Damanik \\ 1,2. Dosen Prodi S-I Keperawatan, STIKes Imelda, Jalan Bilal Nomor 52 Medan \\ E-mail: ediritonga87@gmail.com
}

\begin{abstract}
ABSTRAK
Penilaian kinerja perawat merupakan suatu cara untuk mengevaluasi kinerja perawat sesuai dengan standar praktik profesional, peraturan yang berlaku dan untuk menjamin tercapainya standar praktik keperawatan profesional dan layanan asuhan keperawatan. Berdasarkan wawancara kepada perawat pelaksana dan observasi, bahwa layanan asuhan keperawatan yang diberikan kurang maksimal, pengkajian keperawatan tidak dilakukan secara berkelanjutan, kurangnya modivikasi tindakan keperawatan untuk mengatasi masalah keperawatan yang terjadi pada pasien. Penelitian ini bertujuan untuk mengetahui pengaruh pelatihan dan penerapan penilaian kinerja perawat pelaksana terhadap layanan asuhan keperawatan. Jenis penelitian kuantitatif dengan metode Quasi-Experimental Study dengan desain penelitian two group pre-test-post test design. Peserta pelatihan adalah kepala ruangan pada kelompok intervensi yang berada di Rumah Sakit Umum Imelda Pekerja Indonesia Medan. Responden penelitian untuk pengukuran layanan asuhan keperawatan pada penelitian ini adalah sebanyak 108 perawat pelaksana yang terdiri dari kelompok intervensi yaitu sebanyak 54 orang perawat pelaksana dan pada kelompok kontrol yaitu Rumah Sakit Umum Martha Friska Medan sebanyak 54 orang perawat pelaksana. Berdasarkan hasil penelitian dan dengan melakukan uji statistik yang dilakukan pre test dan post test layanan asuhan keperwatan pada kelompok intervensi dengan uji paired t-test dengan hasil yaitu $p=0,000<0,05$ yang berarti ada pengaruh. Hal ini menunjukkan bahwa pelatihan yang diberikan meningkatkan kemampuan kepala ruangan untuk melakukan penilaian kinerja perawat pelaksana sehingga dapat menigkatakan motivasi dan kinerja perawat pelaksana dalam melakukan layanan asuhan keperawatan. Hasil pre test dan post test layanan asuhan keperwatan pada kelompok kontrol dengan menggunakan uji paired t-test dengan hasil yaitu p=0,284>0,05, hal ini menunjukkan bahwa tidak ada perbedaan yang signifikan antara pre test dan post test. Berdasarkan uji statistik dengan menggunakan independent tes antara pre test kelompok intervensi dan kelompok kontrol didapatkan hasil $p=0,064>0,05$ dan hasil uji post test kelompok intervensi dan kelompok kontrol didapatkan hasil $p=0,000<0,05$. Pelatihan yang diberikan kepada kepala ruangan pada kelompok intervensi sangat berpengaruh positif dalam meningkatkan kemampuan kepala ruangan dalam melakukan penilaian kinerja perawat pelaksana.
\end{abstract}

Kata kunci: Pelatihan, penerapan, penilaian kinerja, layanan asuhan keperawatan.

\section{PENDAHULUAN}

Pelayanan keperawatan merupakan suatu bentuk pelayanan profesional yang merupakan bagian integral dari pelayanan kesehatan yang didasarkan pada ilmu dan kiat keperawatan yang ditujukan kepada individu, keluarga, kelompok, atau masyarakat, baik sehat maupun sakit. Pelayanan kesehatan di rumah sakit berupaya untuk memberikan pelayanan yang berkualitas dengan menerapkan kebijakan, prosedur dan protokol yang sesuai dengan ilmu pengetahuan serta mengikuti Standar Akreditasi Nasional (UU. No.38, 2014).

Undang-undang. No. 38 tahun 2014 tentang keperawatan menjelaskan bahwa perawat adalah seseorang yang telah lulus pendidikan tinggi Keperawatan, baik di dalam maupun di luar negeri yang diakui oleh pemerintah sesuai dengan ketentuan peraturan perundang-undangan. Simamora (2012) mendefinisikan pelayanan keperawata $\mathrm{n}$ sebagai bagian penting dari pelayanan 
kesehatan yang meliputi aspek bio-psikososial-spritual yang komprehensif. Untuk mencapai pelayanan yang berkualitas, kinerja perawat sangat berpengaruh dalam mendukung terselenggaranya pelayanan kesehatan di rumah sakit (Marquis \& Huston, 2010).

Dalam peningkatan kualitas layanan dan juga pengembangan kemampuan perawat, dibutuhkan penilaian kinerja yang efektif untuk mengukur prestasi kerja perawat secara objektif. Metode penilaian kinerja tersebut dapat digunakan sebagai dasar bagi penempatan sumber daya manusia kesehatan pada suatu posisi/jabatan tertentu, serta evaluasi untuk mendorong setiap perawat untuk meningkatkan produktifitas dan mutu pelayanan kesehatan khususnya layanan asuhan keperawatan (Kepmenkes, 2009).

Penilaian kinerja merupakan proses menilai hasil kerja seseorang sesuai dengan indikator yang telah ditetapkan untuk mengetahui kemampuan perawat di bidang pengetahuan dan keterampilan khususnya dalam pelaksanaan asuhan keperawatan, sebagai dasar dalam pengembangan perawat, membantu dalam penentuan kompensasi dan mengetahui adanya penyimpangan dalam pelaksanaan layanan (Rivai, 2011). Penilaian kinerja perawat juga dapat meningkatkan prestasi kerja dan merangsang minat dalam pengembangan (Simamora, 2012). Kinerja perawat yang baik merupakan kunci utama dalam peningkatan kualitas pelayanan kesehatan. Penilaian kinerja perawat merupakan kegiatan mengontrol sumber daya manusia dan produktifitasnya (Swansburg, 2000), suatu ukuran pengawasan yang digunakan oleh manajer perawat (Gillies, 2000). Penelitian yang dilakukan oleh Nikpeyma, dkk (2012) menemukan bahwa penilaian kinerja perawat dilakukan oleh manejerial rumah sakit yang dilakukan terhadap perawat dalam peningkatan pelayanan.

Rumah Sakit Umum Imelda Pekerja Indonesia Medan merupakan rumah sakit yang mengharapkan seluruh karyawan khususnya perawat agar dapat meningkatkan mutu layanan asuhan keperawatan yang diberikan seluruh klien. Berdasarkan hasil wawancara yang dilakukan terhadap kepala bidang keperawatan, dan kepala ruangan di Rumah Sakit Umum Imelda Pekerja Indonesia Medan, diperoleh hasil yaitu belum terlaksananya sistem penilaian kinerja perawat pelaksana, kepala ruangan menyatakan bahwa kurangnya pemahaman mereka tentang cara melakukan penilaian kinerja perawat sehingga penilaian kinerja perawat tidak dilaksanakan. Kepala ruangan memerlukan pelatihan penilaian kinerja perawat pelaksana dalam meningkatkan kemampuan dalam melakukan penilaian.

Berdasarkan studi pendahuluan yang dilakukan terhadap Rumah Sakit Umum Martha Friska Medan ditemukan bahwa penilaian kinerja perawat pelaksana tidak berjalan dengan baik sehubungan dengan kurangnya kemampuan kepala ruangan dalam melakukan penilaian kinerja terhadap perawat pelaksana. Berdasarkan wawancara kepada perawat pelaksana dan observasi, bahwa layanan asuhan keperawatan yang diberikan kurang maksimal, pengkajian keperawatan tidak dilakukan secara berkelanjutan, kurangnya modivikasi tindakan keperawatan untuk mengatasi masalah keperawatan yang terjadi pada pasien.

\section{METODE}

Tujuan dari penelitian ini untuk mengetahui pengaruh pelatihan dan penerapa $\mathrm{n}$ penilaian kinerja perawat pelaksana terhadap layanan asuhan keperawatan di Rumah Sakit Umum Swasta Kota Medan. Penelitian ini merupakan penelitian kuantitatif dengan menggunakan rancangan penelitian metode Quasi-Eksperimental Study dengan desain penelitian two group pre-testpost test design (Polit \& Beck. 2012).

Populasi dalam penelitian ini dibagi dalam dua populasi yaitu perawat pelaksana yang berada di RSU Imelda Pekerja Indonesia Medan (kelompok intervensi) dan perawat pelaksana di RSU Martha Friska Medan (kelompok kontrol). Teknik pengambilan sampel pada populasi perawat pelaksana dengan random sampling sistematis dengan jumlah sampel pada perawat pelaksana sebanyak 108 orang, 54 
orang pada kelompok intervensi dan 54 orang pada kelompok kontrol.

Pengambilan data dilakukan langsung dari responden yaitu perawat pelaksana berdasarkan instrumen penelitian yang tentang layanan asuhan keperawatan dengan cara pre-test dan post-test pada kelompok intervensi dan pada kelompok kontrol. Analisis data menggunakan analisis univariat, analisis bivariat dengan uji paired t-test dan independent test. Sebelum dilakukan penelitian, peneliti menyampaikan informasi yang akan dilakukan kepada respon den, yaitu tujuan penelitian, manfaat penelitian, kegiatan yang dilakukan selama penelitian dan hak-hak responden dalam penelitian ini. Calon responden yang bersedia menandatangani lembar persetujuan (informed consent).

HASIL

Tabel 1. Karakteristik Demografi Perawat Pelaksana $(\mathrm{N}=108)$.

\begin{tabular}{lcccc}
\hline Karakteristik & $\begin{array}{c}\text { F } \\
\text { (Kelom } \\
\text { pok } \\
\text { Intervensi) }\end{array}$ & $\begin{array}{c}\text { \% } \\
\text { (Kelom } \\
\text { pok } \\
\text { Kontrol) }\end{array}$ & \% \\
\hline Umur & 38 & 70,4 & 12 & 22,3 \\
21-25 tahun & 14 & 25,9 & 20 & 37 \\
\hline 26-30 tahun & 2 & 3,7 & 22 & 40,7 \\
\hline 30 tahun & & & & \\
\hline Jenis kelamin & 23 & 42,6 & 16 & 29,6 \\
Laki-laki & 31 & 57,4 & 38 & 70,4 \\
Perempuan & & & & \\
Pendidikan & 42 & 77,8 & 41 & 75,9 \\
DIII & 8 & 14,8 & 1 & 1,9 \\
Keperawatan & 4 & 7,4 & 12 & 22,2 \\
S1 Kep & & & & \\
Ners & & & & \\
\hline Masa kerja & 27 & 50 & 15 & 27,8 \\
1-2 tahun & 22 & 40,7 & 26 & 47,1 \\
3-5 tahun & 5 & 9,3 & 13 & 24,1 \\
\hline > 5 tahun & 5
\end{tabular}

Berdasarkan tabel diatas, dapat dilihat bahwa mayoritas umur responden pada kelompok intervensi antara 21-25 tahun yaitu sebanyak 38 orang $(70,4 \%)$ dan minoritas $>30$ tahun sebanyak 2 orang $(3,7 \%)$. Berdasarkan jenis kelamin mayoritas responden adalah perempuan yaitu sebanyak 31 orang $(57,4 \%)$, mayoritas pendidikan responden adalah DIII Keperawatan yaitu sebanyak 42 orang $(77,8 \%)$ dan mayoritas masa kerja responden adalah 1-2 tahun yaitu sebanyak 27 orang (50\%).

Berdasarkan tabel diatas pada kelompok kontrol mayoritas responden berumur $>30$ tahun yaitu sebanyak 22 orang $(40,7 \%)$ dan minoritas berumur 21-25 tahun yaitu sebanyak 12 orang $(22,3 \%)$, mayoritas responden berjenis kelamin perempuan yaitu sebanyak 38 orang $(70,4 \%)$, mayoritas pendidikan responden adalah DIII Keperawatan yaitu sebanyak 41 orang $(75,9 \%)$ dan mayoritas masa kerja responden adalah 3-5 tahun yaitu sebanyak 26 orang $(47,1)$.

Tabel 2. Distribusi Frekuensi Pre Test Layan an Asuhan Keperawatan ( $\mathrm{N}=108)$.

\begin{tabular}{lllll}
\hline $\begin{array}{c}\text { Layanan } \\
\begin{array}{c}\text { Asuhan } \\
\text { Keperawata } \\
\mathbf{n}\end{array}\end{array}$ & $\begin{array}{c}\text { F } \\
\text { (Inter } \\
\text { vensi) }\end{array}$ & $\begin{array}{c}\text { F } \\
(\%)\end{array}$ & $\begin{array}{c}\text { (Kon } \\
\text { trol) }\end{array}$ & $(\%)$ \\
\hline Baik & 6 & 11,1 & 19 & 35,2 \\
\hline Kurang & 48 & 89,9 & 35 & 64,8 \\
\hline Jumlah & 54 & 100 & 54 & 100 \\
\hline
\end{tabular}

Berdasarkan tabel di atas menunjukkan bahwa hasil penelitian yang telah dilakukan layanan asuhan keperawatan sebelum dilakukan intervensi (pre test) yang berupa pelatihan penilaian kinerja perawat pelaksana pada kelompok intervensi adalah mayoritas kurang yaitu sebanyak 48 orang $(89,9 \%)$ dan minoritas adalah baik yaitu sebanyak 6 orang $(11,1 \%)$. Pre test layanan asuhan keperawatan pada kelompok kontrol adalah mayoritas kurang yaitu sebanyak 35 orang $(64,8 \%)$ dan minoritas adalah baik yaitu sebanyak 19 orang $(35,2 \%)$.

Tabel 3. Distribusi Frekuensi Post Test Layanan Asuhan Keperawatan ( $\mathrm{N}=108)$.

\begin{tabular}{ccccc}
$\begin{array}{c}\text { Layana } \\
\mathbf{n} \\
\begin{array}{c}\text { Asuhan } \\
\text { Kepera } \\
\text { watan }\end{array}\end{array}$ & $\begin{array}{c}\mathbf{F} \\
(\mathbf{I n t e} \\
\text { rvens } \\
\text { i) }\end{array}$ & $(\boldsymbol{\%})$ & $\begin{array}{c}\mathbf{F} \\
(\text { Kon } \\
\text { trol) }\end{array}$ & $(\boldsymbol{\%})$ \\
\hline Baik & 51 & 94,4 & 21 & 38,9 \\
\hline Kurang & 3 & 5,6 & 33 & 61,1 \\
\hline Jumlah & 54 & 100 & 54 & 100 \\
\hline
\end{tabular}

Berdasarkan tabel diatas menunjukkan bahwa hasil penelitian yang dilakukan yaitu post test layanan asuhan keperawatan setelah 
dilakukan intervensi pelatihan penilaian kinerja perawat pelaksana pada kelompok intervensi adalah mayoritas baik yaitu sebanyak 51 orang $(94,4 \%)$ dan minoritas adalah kurang yaitu sebanyak 3 orang $(5,6 \%)$. Post test Layanan asuhan keperawatan pada kelompok kontrol adalah mayoritas kurang yaitu sebanyak 33 orang $(61,1 \%)$ dan minoritas adalah baik yaitu sebanyak 21 orang $(38,9 \%)$.

Tabel 4. Uji Statistik Layanan Asuhan Keperawatan Kelompok Intervensi (N=54).

$\begin{array}{ll}\begin{array}{l}\text { Layanan Asuhan } \\ \text { Keperawatan }\end{array} \quad \text { Mean } & \begin{array}{l}\text { Sig. (2- } \\ \text { tailed) }\end{array}\end{array}$

\begin{tabular}{lc}
\hline Sebelum & 45.333 \\
\hline Sesudah & 60.277
\end{tabular}

Hasil uji statistik menunjukkan bahwa layanan asuhan keperawatan sebelum dan sesudah dilakukan pelatihan dan penerapan pada kelompok intervensi ditemukan bahwa terdapat pengaruh yang signifikan dengan menggunakan uji paired t-test dengan hasil yaitu $p=$ $0,000<0,05$. Hal ini menunjukkan bahwa pelatihan yang diberikan kepada kepala ruangan sangat berpengaruh positif, kemampuan kepala ruangan menigkat dalam melakukan penilaian kinerja perawat pelaksana.

Tabel 5. Uji Statistik Layanan Asuhan Keperawatan Kelompok Kontrol (N=54).

\begin{tabular}{lll}
\hline $\begin{array}{l}\text { Layanan Asuhan } \\
\text { Keperawatan }\end{array}$ & Mean & $\begin{array}{l}\text { Sig. (2- } \\
\text { tailed) }\end{array}$ \\
\hline Sebelum & 47.533 & \\
\cline { 1 - 2 } Sesudah & 47.796 &
\end{tabular}

Hasil uji statistic diatas menunjukkan bahwa pre test dan post test layanan asuhan keperawatan pada kelompok kontrol dengan hasil $p=0,284>0,05$ dengan arti tidak ada per bedaan yang signifikan antara pre test dan post layanan asuhan keperawatan. Pada kelompok kontrol tidak ada intervensi yang diberikan sehingga layanan asuhan keperawat an tidak perbedaan yang signifikan.

Tabel 6. Uji Statistik Pre Test Layanan Asuhan Keperawatan Kelompok Intervensi dan Kelompok Kontrol ( $\mathrm{N}=108)$.

\begin{tabular}{lcc}
$\begin{array}{l}\text { Layanan Asuhan } \\
\text { Keperawatan }\end{array}$ & t & $\begin{array}{l}\text { Sig. } \\
\text { tailed) }\end{array}$ \\
\cline { 1 - 1 } Kelompok Intervensi & (2- \\
\cline { 1 - 1 } $\begin{array}{l}\text { Kelompok } \\
\text { Kontrol }\end{array}$ & & 0,064 \\
\hline
\end{tabular}

Berdasarkan tabel di atas, dari hasil uji statistik independent tes menunjukkan bahwa $p=0,064>0,05$. Hal ini menunjukkan bahwa tidak ada perbedaan layanan asuhan keperawatan sebelum dilakukan pelatihan dan penerapan pada kelompok intervensi dengan kelompok kontrol.

Tabel 7. Uji Statistik Post Test Layanan Asuhan Keperawatan Kelompok Intervensi dan Kelompok Kontrol $(\mathrm{N}=108)$.

\begin{tabular}{lcc}
\hline $\begin{array}{l}\text { Layanan Asuhan } \\
\text { Keperawatan }\end{array}$ & t & Sig. (2-tailed) \\
\hline $\begin{array}{l}\text { Kelompok } \\
\text { Intervensi }\end{array}$ & 10.09 & \\
\cline { 1 - 2 } Kelompok & 0 & 0,000 \\
Kontrol & & \\
\hline
\end{tabular}

Berdasarkan tabel di atas, dari hasil uji statistik yang dilakukan menunjukkan bahwa $p=0,000<0,05$. Hal ini menunjukkan bahwa terdapat perbedaan layanan asuhan keperawatan pada kelompok intervensi dan kelompok kontrol. Pelatihan yang diberikan kepada kepala ruangan sangat berpengaruh positif, kemampuan kepala ruangan menigkat dalam melakukan penilaian kinerja perawat pelaksana dalam kelompok intervensi sehingga perawat pelaksana termotivasi dalam melakukan layanan asuhan keperawatan.

\section{PEMBAHASAN}

\section{Layanan Asuhan Keperawatan Pada Kelompok Intervensi dan Kelompok Kontrol.}

Hasil penelitian menunjukkan distribusi frekuensi berdasarkan layanan asuhan keperawatan sebelum dilakukan intervensi (pre test) pelatihan penilaian kinerja perawat pelaksana pada kelompok intervensi adalah 
mayoritas kurang yaitu sebanyak 48 orang $(89,9 \%)$ dan minoritas adalah baik yaitu sebanyak 6 orang $(11,1 \%)$. Layanan asuhan keperawatan sebelum dilakukan intervensi (pre test) pelatihan penilaian kinerja perawat pelaksana pada kelompok kontrol adalah mayoritas kurang yaitu sebanyak 35 orang $(64,8 \%)$ dan minoritas adalah baik yaitu sebanyak 19 orang $(35,2 \%)$.

Hasil penelitian yang dilakukan diperoleh distribusi frekuensi berdasarkan layanan asuhan keperawatan setelah dilakukan intervensi (post test) pelatihan penilaian kinerja perawat pelaksana pada kelompok intervensi adalah mayoritas baik yaitu sebanyak 51 orang $(94,4 \%)$ dan minoritas adalah kurang yaitu sebanyak 3 orang $(5,6 \%)$. Layanan asuhan keperawatan setelah dilakukan intervensi (post test) pelatihan penilaian kinerja perawat pelaksana pada kelompok kontrol adalah mayoritas kurang yaitu sebanyak 33 orang $(61,1 \%)$ dan minoritas adalah baik yaitu sebanyak 21 orang $(38,9 \%)$.

Dalam penelitian ini pengukuran layanan asuhan keperawatan dengan penerapan standar asuhan keperawatan yaitu standar I pengkajian keperawatn, standar II diagnosa keperawatan, standar III perencanaan, standar IV implementasi, dan standar V evaluasi (Potter \& Perry, 2009). Menurut peneliti berdasarkan penelitian yang dilakukan bahwa dalam memberikan layanan asuhan keperawatan perawat tidak sepenuhnya menerapkan proses keperawatan terhadap klien, hal ini dapat dilihat juga dari pendokumentasian yang ditemukan bahwa pelaksanaan asuhan keperawatan tidak maksimal. Pada proses keperawatan yaitu pengkajian perawat pelaksana sudah cukup dalam melakukan dan juga melakukan pendokumentasian, penegakan diagnose keperawatan tidak mencerminkan rumus diagnosa keperawatan yaitu PE/PES. Pada tindakan keperawatan, perawat terlihat jarang dalam memberikan pendidikan kesehatan terhadap klien tentang penyakitnya.

Pelatihan yang diberikan tentang penilaian kinerja perawat pelaksana sangat berpengaruh terhadap kemampuan kepala ruangan dan bidang keperawatan dalam melakukan penilaian kinerja perawat pelaksana, dimana hal ini diharapkan setelah dilakukan penilaian kinerja perawat dapat meningkatkan motivasi dalam bekerja dan produktivitas dari perawat pelaksana dalam melakukan layanan asuhan keperawatan yang diberikan kepada klien. Pelayanan keperawatan merupakan bagian integral dari suatu kinerja pelayanan kesehatan. Profesi perawat sebagai pemberi pelayanan jasa berada digaris terdepan dan merupakan komponen yang sangat menentukan baik kurangnya citra rumah sakit.

\section{Perbedaan Layanan Asuhan Keperawatan Pada Kelompok Intervensi dan Pada Kelompok Kontrol.}

Berdasarkan hasil uji statistik yang dilakukan antara layanan asuhan keperwatan sebelum dilakukan pelatihan dan penerapan pada kelompok intervensi dan layanan asuhan keperawatan pada kelompok kontrol dan menunjukkan bahwa $p=0,064>0,05$. Hal ini menunjukkan bahwa tidak ada perbedaan layanan asuhan keperawatan sebelum dilakukan pelatihan dan penerapan pada kelompok intervensi dengan kelompok kontrol.

Hasil hasil uji statistik yang dilakukan antara layanan asuhan keperwatan setelah dilakukan pelatihan dan penerapan pada kelompok interyensi dan layanan asuhan keperawatan post test pada kelompok kontrol menunjukkan bahwa $p=0,000<0,05$. Hal ini menunjukkan bahwa terdapat perbedaan layanan asuhan keperawatan pada kelompok intervensi dan kelompok kontrol. Pelatihan yang diberikan kepada kepala ruangan sangat berpengaruh positif, kemampuan kepala ruangan menigkat dalam melakukan penilaian kinerja perawat pelaksana dalam kelompok intervensi sehingga layanan asuhan keperawatan dapat terlaksana dengan baik.

Kemampuan kepala ruangan yang sudah baik sangat diharapkan setelah dilakukan intervensi terhadap kepala ruangan, penilaian kinerja terhadap perawat pelaksana diterapkan di Rumah Sakit Umum Imelda Pekerja Indonesia Medan untuk melihat ataupun mengevaluasi hasil kerja dari perawat pelaksana dalam melaksanakan 
asuhan keperawatan. Penilaian kinerja dilaksanakan dapat memotivasi perawat pelaksana dalam meningktatakn kinerja khususnya dalam melakukan asuhan keperawatan, menunjang kualitas layanan asuhan keperawatan yang baik diberikan kepada pasien. Kinerja (prestasi kerja) adalah hasil kerjasama kualitas dan kuantitas yang dicapai oleh seorang pegawai dalam melaksanakan tugasnya sesuai dengan tanggung jawab yang diberikan kepadanya dan juga upaya mencapai tujuan oganisasi bersangkutan, secara legal, tidak melanggar hukum dan sesuai dengan norma dan etika (Buheli, 2010).

Kinerja perawat adalah hasil kerja atau produktivitas yang dilakukan perawat sesuai dengan standar terhadap tugas dan peranan yang diberikan (Simamora, 2012). Gillies (1996) menyatakan penilaian kinerja perawat dilakukan dengan tujuan membantu memperbaiki pelaksanaan kerja mereka, memberitahu pekerja yang tidak memuaskan bahwa pelaksanaan kerja mereka kurang serta menganjurkan metode perbaikannya, mengidentifikasi pegawai yang layak menerima promosi atau kenaikan gaji, memperbaiki komunikasi antara dirinya sendiri dan bawahan, sebagai salah satu hal yang memotivasi perawat dalam meningkatkan kinerjanya.

Gillies (1996) menyatakan pelatihan merupakan proses pembentuk karyawan untuk memperoleh efektivitas dalam pekerjaan dan merupakan salah satu kegiatan pengembangan staf yang bertujuan untuk meningkatkan mutu sumber daya manusia. Marquis dan Huston (2010), menyatakan bahwa pelatihan yang diberikan tentang penilaian kinerja dapat menigkatkan pemahaman dan kemampuan bagi menejer dalam melaksanakan penilaian kinerja perawat.

Hasil penelitian menunjukkan bahwa pelatihan memiliki pengaruh terhadap kinerja perawat, pelatihan merupakan sebuah upaya yang bertujuan untuk membekali, meningkatkan, dan mengembangkan kompetensi kerja guna meningkatkan kemampuan, produktivitas dan kesejahteraan (Simamora, 2006).
Gillies (1996) menyatakan penilaian kinerja perawat dilakukan dengan tujuan membantu kepuasan pekerja untuk memperbaiki pelaksanaan kerja mereka, memberitahu pekerja yang tidak memuaskan bahwa pelaksanaan kerja mereka kurang serta menganjurkan metode perbaikannya, mengidentifikasi pegawai yang layak menerima promosi atau kenaikan gaji, mengenal pegawai yang memenuhi syarat penugasan khusus, memperbaiki komunikasi antara dirinya sendiri dan bawahan, sebagai salah satu hal yang memotivasi perawat dalam meningkatkan kinerjanya. Selain itu penilaian kinerja perawat juga bertujuan untuk memotivasi perawat untuk meningkatkan kinerjanya, untuk mengidentifikasi kebutuhan perawat tentang pendidikan dan mengkaji kualitas asuhan keperawatan yang diberikan perawat kepada pasien.

Motivasi adalah sebuah dorongan atau keinginan untuk mencapai tingkatan usaha yag lebih tinggi ke arah tujuan organisasi atau suatu keinginan untuk berusaha memberi pemenuhan kebutuhan individu. Penilaian kinerja yang berdampak pada peningkatan motivasi kerja dalam penigkatan produktivitas merupakan faktor yang dapat mempengaruhi kualitas dari layanan asuhan keperawatan yang diberikan dalam suatu rumah sakit. Layanan keperawatan yang diberikan harus sesuai dengan standar. Standar pelayanan keperawatan merupakan pedoman untuk perawat dalam melakukan praktik keperawatan yang digunakan untuk menentukan apakah perawat telah bertindak sesuai prosedur (Potter \& Perry, 2005).

Berdasarkan penelitian yang dilakukan oleh Buheli Kartin (2010) bahwa faktor yang mempengaruhi seseorang dalam melaksanakan asuhan keperawatan adalah motivasi. Atanay (2008) faktor yang mempengaruhi layanan asuhan keperawatan pengetahuan, motivasi dan kepemimpinan, Hasmoko (2008) pengetahuan, sikap, motivasi dan monitoring. Perawat yang mempunyai motivasi tinggi terdorong untuk lebih giat melaksanakan tugasnya. Motivasi berkaitan erat dengan dorongan yang kuat untuk melakukan setiap pekerjaan dengan 
hasil yang optimal. Berbeda dengan yang tidak memiliki motivasi tinggi maka ia tidak memiliki hasrat untuk berkerja semaksimal mungkin serta bersikap apatis terhadap tugasnya yang mengakibatkan kinerjanya kurang baik.

Menurut peneliti faktor pendidikan responden berpengaruh dalam layanan asuhan keperawatan, dari hasil penelitian bahwa pendidikan responden mayoritas DIII Keperawatan. Menurut penelitian Eizenberg, (2011), menyatakan bahwa faktor yang berhubungan dengan kualitas asuhan keperawatan diantaranya faktor pendidikan. Sedangkan menurut Istomina, Razbadaukas, dan Martinkenas, (2014) bahwa usia merupak an salah satu faktor yang mempengaruhi layanan asuhan keperawatan. Di sisi lain responden menyatakan permohonan apabila mereka memiliki kinerja yang baik dan layanan asuhan keperawatan yang diberikan kepada klien sudah baik, mereka mengharapkan adanya imbalan ataupun penghargaan berupa kompensasi/peningkatan gazi.

\section{KESIMPULAN}

Berdasarkan hasil uji statistik yang dilakukan antara layanan asuhan keperwatan sebelum dilakukan pelatihan dan penerapan pada kelompok intervensi dan layanan asuhan keperawatan pada kelompok kontrol dan menunjukkan bahwa $p=0,064>0,05$. Hal ini menunjukkan bahwa pelatihan yang diberikan kepada kepala ruangan sangat berpengaruh positif, kemampuan kepala ruangan menigkat dalam melakukan penilaian kinerja perawat pelaksana dalam kelompok intervensi.

Hasil hasil uji statistik yang dilakukan antara layanan asuhan keperwatan setelah dilakukan pelatihan dan penerapan pada kelompok intervensi dan layanan asuhan keperawatan post test pada kelompok control menunjukkan bahwa $p=0,000<0,05$. Hal ini menunjukkan bahwa terdapat perbedaan layanan asuhan keperawatan pada kelompok intervensi dan kelompok kontrol. Pelatihan yang diberikan kepada kepala ruangan sangat berpengaruh positif, kemampuan kepala ruangan menigkat dalam melakukan penilaian kinerja perawat pelaksana.

\section{SARAN}

1) Rumah sakit Diharapkan kepada Rumah Sakit untuk melakukan kontroling dalam pelaksanaa $\mathrm{n}$ penilaian kinerja perawat pelaksana. Buku panduan dan instrumen penelitian dapat digunakan oleh rumah sakit untuk implikasi.

2) Pendidikan keperawatan

Hasil penelitian ini dapat dijadikan sebagai sumber informasi bagi pendidika $\mathrm{n}$ keperawatan tentang penilaian kinerja perawat pelaksana dan layanan asuhan keperawatan di rumah sakit. Diharapkan pendidikan keperawatan

\section{DAFTAR PUSTAKA}

Atanay, R. S. (2008). Analisis faktor-faktor yang mempengaruhi kinerja perawat dalam melaksanakan asuhan keperawatan di Rumah Sakit umum fakfak. Universitas Diponegoro

Buheli, K, (2010). Faktor yang mempengaruhi kinerja perawat dalam penerapan proses keperawatan di RSUD Toto Kabupaten Bone Bolango. Politeknik Kesehatan Kemenkes Gorontalo.

Departemen Kesehatan Republik Indonesia (1994). Diakses dari http://depkes.go.id/ pada tanggal 17 Januari 2016.

Depkes RI. (2014). Undang-undang republik indonesia Nomor 38 tahun 2014 Tentang Keperawatan. Jakarta: Departemen Kesehatan.

Eizenberg, M. M. (2011). Implementation of evidence-based nursing practice: nurses' personal and professional factors. Journal of Advanced Nursing, 67(1), 3342. doi: $\quad 10.1111 / \mathrm{j} .1365-$ 2648.2010.05488

Ellis, J. R., \& Hartley, C. L. (2012). Nursing in today's world: trends, issues and management $\left(10^{\text {th }}\right.$ ed $)$. Philadelphia: Wolters Kluwer. 
Gillies, D. A. (1996). Manajemen keperawata $n$ suatu pendekatan sistem. Edisi Ke Dua. Jakarta.

Hasmoko, E.V. (2008). Analisis faktor-faktor yang mempengaruhi kinerja klinis perawat berdasarkan penerapan sistem pengembangan manajemen kinerja klinis (spmkk) di ruang rawat inap Rumah Sakit Panti Wilasa Citarum Semarang. Tesis Universitas Diponegor.

Istomina, N. R.A., \& Martinkenas, A. (2014). Evaluations related to the quality of health and nursing care of patients after abdominal surgery. Lithuanian Surgery, 123(1), 25-30.

Kepmenkes. RI. 2009. Nomor 857/Menkes/Sk /IX/2009 Tentang Pedoman Penilaian kinerja sumber daya manusia kesehatan di puskesmas. Jakarta

Marquis, B.L., \& Huston, C. J. (2010). Kepemimpinan dan manajemen keperaw atan: teori dan aplikasi. (edisi 4). Jakarta: EGC.

Nikpeyma, N., Saeedi, Z. A., Azargashb, E., \& Majd, H. A. (2013). Problem of clinical nurse performance appraisal system : A qualitative study. Asian Nursing Research, 300, 1-8.

PPNI, (2005). Standar praktik keperawatan Indonesia. PP-PPNI Melalui http://www.inna-ppni.or.id.
Polit, D. F., \& Beck, C. T. (2012). Nursing: generating and assessing evidence for nursing practice. ( $9^{\text {th }}$ ed.). Philadelpia: Lippincott.

Potter \& Perry. (2009). Fundamental of nursing. Edisi Ke 7. Buku 1. Jakarta; Salemba Medika.

Profil RSU Imelda Pekerja Indonesia Medan. (2015). Tidak dipublikasikan.

Rivai, V, dkk (2010). Performance managem ent dari teori ke praktik. Jakarta: Raja Grafindo Persada.

Simamora H. R. (2012). Buku ajar menejemen keperawatan. Jakarta: EGC.

Swansburg, R.C. (2000). Pengantar kepemim pinan dan manajemen keperawatan untuk perawat klinis. Alih bahasa, Suharyati Samba; editor, Monica Ester. Jakarta: EGC.

Undang-Undang Republik Indonesia Nomor 38, (2014). Tentang Keperawatan. Jakarta: Departemen Kesehatan.

Vasset, F., Marnburg, E., Furunes, T. (2010). Employees' perceptions of justice in performance appraisals. Journal Nursing Management, 17 (2), 30-34.

Vasset, F., Marnburg, E., Furunes, T. (2011). The effects of performance appraisal in the Norwegian municipal health services: a case study, BioMed Central, 9(22). 1-12. 